\title{
Ketamine Inhibits Proliferation of Neural Stem Cell from Neonatal Rat Hippocampus in Vitro
}

\author{
Yu-Qing Wu Wuo Liang $^{\mathrm{a}, \mathrm{b}}$ He Huang ${ }^{\mathrm{a}}$ Yang-Zi Zhu ${ }^{\mathrm{a}}$ Pan-Pan Zhao \\ Chun-Mei Xua Lu Liu ${ }^{a}$ Xiao-Tian Shic Yu Hua Li Huang ${ }^{c}$ Cheng-Hua Zhou
}

ajiangsu Province Key Laboratory of Anesthesiology, Xuzhou Medical College, Xuzhou, bepartment of Anesthetic Pharmacology, Xuzhou Medical College, Xuzhou, 'Department of Pharmacology, School of Pharmacy, Xuzhou Medical College, Xuzhou, P R. China

\section{Key Words}

Ketamine $\cdot$ Neural stem cell $\cdot$ Proliferation $\cdot$ Developing brain

\begin{abstract}
Background/Aims: Ketamine is a widely used anesthetic in obstetric and pediatric anesthesia. In the developing brain, the widespread neuron apoptosis triggered by ketamine has been demonstrated. However, little is known about its effect on neural stem cells (NSCs) function. This study aimed to investigate the effect of ketamine on proliferation of NSCs from neonatal rat hippocampus. Methods: Neural stem cells were isolated from the hippocampus of Sprague-Dawley rats on postnatal day 3. In dose-response experiments, cultured neural stem cells (NSCs) were exposed to different concentrations of ketamine $(0-1000 \mu \mathrm{M})$ for 24 hrs. The proliferative activity of NSCs was evaluated by 5-Bromo-2'-deoxyuridine (BrdU) incorporation assay. Apoptosis of neural stem cells were assessed using caspase- 3 by western blot. The intracellular $\mathrm{Ca}^{2+}$ concentration $\left(\left[\mathrm{Ca}^{2+}\right] \mathrm{i}\right)$ in NSCs was analyzed by flow cytometry. The activation of protein kinase $\mathrm{C}-\alpha(\mathrm{PKC} \alpha)$ and the phosphorylation of extracellular signalregulated kinases $1 / 2$ (ERK1/2) were measured by western blot analysis. Results: Clinical relevant concentration of ketamine $(10,20$ and $50 \mu \mathrm{M})$ did not markedly alter the proliferation of NSCs from neonatal rat hippocampus in vitro. However, ketamine $(200,500,800$ and $1000 \mu \mathrm{M})$ significantly inhibited the proliferation of NSCs and did not affect the expression of caspase-3. Meanwhile, ketamine $(200,500,800$ and $1000 \mu \mathrm{M})$ also markedly decreased $\left[\mathrm{Ca}^{2+}\right]$ $i$ as well as suppressed PKC $\alpha$ activation and ERK1/2 phosphorylation in NSCs. A combination of subthreshold concentrations of ketamine $(100 \mu \mathrm{M})$ and $\mathrm{Ca}^{2+}$ channel blocker verapamil $(2.5 \mu \mathrm{M}), \mathrm{PKC} \alpha$ inhibitor chelerythrine $(2.5 \mu \mathrm{M})$ or ERK1/2 kinase inhibitor PD98059 $(5 \mu \mathrm{M})$ significantly produced suprathreshold effects on PKC $\alpha$ activation, ERK1/2 phosphorylation and NSC proliferation. Conclusion: Ketamine inhibited proliferation of NSCs from neonatal rat hippocampus in vitro. Suppressing $\mathrm{Ca}^{2+}-\mathrm{PKC} \alpha-\mathrm{ERK} 1 / 2$ signaling pathway may be involved in this inhibitory effect of ketamine on NSCs proliferation.

Copyright @ 2014 S. Karger AG, Basel
\end{abstract}

Y.-Q. Wu, T. Liang and $\mathrm{H}$. Huang contribute equally to this work.

Dr. Yu-Qing Wu,

and Dr. Cheng-Hua Zhou

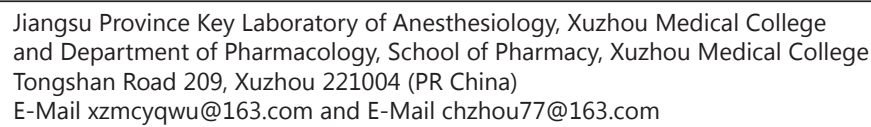

Jiangsu Province Key Laboratory of Anesthesiology, Xuzhou Medical College and Department of Pharmacology, School of Pharmacy, Xuzhou Medical College Tongshan Road 209, Xuzhou 221004 (PR China)

E-Mail xzmcyqwu@163.com and E-Mail chzhou77@163.com 


\section{Introduction}

Ketamine is an intravenous anesthetic that is being widely used in obstetric and pediatric anesthesia. The precise mechanisms for general anesthesia of ketamine are not completely elucidated but are considered to be dependent on blocking N-methyl-D-aspartate (NMDA) receptor ion channel. Initially, interest in the effect of NMDA-receptor antagonists on the developing brain was focused on preventing hypoxic/ischemic brain damage [1]. Subsequent studies, however, suggested that, in the developing brain, NMDA-receptor antagonists may also have direct neurotoxic effects. It was reported that blockade of NMDA glutamate receptors for only a few hours during late fetal or early neonatal life triggered widespread apoptotic neurodegeneration in the developing rodent and nonhuman primates brain [2-5].

Besides the acute toxicity characterized as apoptotic neurodegeneration, the longterm adverse effects produced by ketamine exposure in developing brain were also clearly demonstrated both in rodent and primates animals. It was showed that exposure to ketamine during a critical stage of brain development resulted in long-lasting behavioral and cognitive deficits in adulthood [6, 7]. In addition, two retrospective clinical studies [8, 9] suggest that anesthetic exposure early in life is closely associated with learning and behavioral abnormalities later in life.

Although more and more studies revealed that ketamine exposure in developing brain can cause neuronal apoptosis and lead to subsequent neurocognitive dysfunction, little is known about the effect of ketamine on hippocampal neurogenesis. Neurogenesis is critical to normal hippocampal function and even limited suppression of neurogenesis is associated with the development of significant cognitive deficits [10]. The process of hippocampal neurogenesis involves proliferation of neural stem cells (NSCs), differentiation into neurons and glia, migration and functional integration into the hippocampal neural circuit $[11,12]$. In this complicated neurogenesis process the proliferation of NSCs was not only initial but also very crucial. This study aims to investigate the effect of ketamine on hippocampal NSCs proliferation and relevant mechanism.

\section{Materials and Methods}

\section{Hippocampal NSCs culture}

New-born Sprague-Dawley rats were purchased from Laboratory Animal Centre of Xuzhou Medical College. The experimental procedures were approved by XuZhou Medical College Committee on Animal Care. The NSCs from hippocampus of postnatal day 3 (P3) rats were isolated and propagated by a neurosphere method developed by Reynolds and Weiss [13]. The isolated cells were resuspended in free-serum medium of DMEM/F12 (1:1, Gibco, Grand Island, USA) which was supplemented with 2\% B27 (Invitrogen, Grand Island, USA) without vitamin A, $20 \mathrm{ng} / \mathrm{ml}$ epidermal growth factor (EGF, PeproTech, Rocky Hill, USA), 20 $\mathrm{ng} / \mathrm{ml}$ basic fibroblast growth factor (bFGF, PeproTech, Rocky Hill, USA), and $100 \mathrm{U} / \mathrm{ml}$ penicillin and phytomycin. A half of culture medium was replaced every 3 days. Cells were incubated for 7 days to form enough neurospheres. Then neurospheres were collected, dissociated with accutase (Sigma, Saint Louis, USA) for $10 \mathrm{~min}$ and then passaged at a cell density of $2 \times 10^{5}$ cells $/ \mathrm{mL}$.

\section{5-Bromo-2'-deoxyuridine (BrdU) incorporation assay}

Briefly, the single cell suspensions of NSCs from neurospheres on the sixth day were incubated with the proliferation marker $\mathrm{BrdU}(10 \mu \mathrm{g} / \mathrm{L})$ for $24 \mathrm{~h}$ at various concentrations of racemic ketamine $(0,10$, $20,50,100,200,500,800$ and $1000 \mu \mathrm{M})$. After incubation, the dissociated cells were seeded onto $100 \mu \mathrm{g} /$ $\mathrm{mL}$ poly-L-lysine-coated coverslips. Then they were stained for the NSC marker nestin and BrdU marker [14]. To detect nestin, the primary antibody was rabbit anti-nestin polyclonal antibody and the secondary antibody was Cy3 conjugated goat anti-rabbit IgG. To detect BrdU, the primary antibody was mouse antiBrdU monoclonal antibody and the second antibody was fluorescein isothiocyanate (FITC) conjugated goat anti-mouse IgG. Immunoreactive cells were visualized by fluorescence microscopy. 
$\mathrm{Ca}^{2+}$ concentration measurement

The NSCs from neurospheres on the sixth day were incubated with various concentrations of ketamine for $24 \mathrm{~h}$. Intracellular $\mathrm{Ca}^{2+}$ concentration $\left(\left[\mathrm{Ca}^{2+}\right] \mathrm{i}\right)$ was determined with the $\mathrm{Ca}^{2+}$-sensititive fluorochrome Fluo-3/acetoxymethyl ester (Fluo-3/AM) by a Becton Dickinson FACS Calibur flow cytometer [15]. Cells were washed 2 times with D-Hanks' solution and resuspended to prepare $1 \times 10^{6}$ cells per ml solution. Cells were incubated with $4 \mathrm{uM}$ Fluo-3/AM (Dojindo,Kumamoto, Japan) at $37{ }^{\circ} \mathrm{C}$ for $30 \mathrm{~min}$ in the dark. Then the loaded cells were gently rinsed two times with D-Hanks' solution and the fluorescence intensity was analyzed by flow cytometry. The excitation wavelength and emission wavelength were $488 \mathrm{~nm}$ and $525 \mathrm{~nm}$.

\section{Western blot analysis}

The expressions of caspase-3, PKC $\alpha$ (membrane protein) and phosphorylated ERK1/2 were measured by western blot analysis after treatment with various concentrations of ketamine for $24 \mathrm{~h}$. Cells were washed with ice-cold D-hanks' solution three times and then lysed with lysis buffer containing protease and phosphatase inhibitors (KeyGEN, China). The cell lysates were placed on ice for $15 \mathrm{~min}$ and centrifuged at $14000 \mathrm{rpm}$ for $15 \mathrm{~min}$ at $4^{\circ} \mathrm{C}$. Protein concentrations in the resulting lysates were determined with a BCA protein assay kit, bovine serum albumin (BSA) was used as a standard. Equal amounts of the resulting cell lysate was resolved by sodium dodecyl sulfate-polyacrylamide gel and the separated proteins were transferred to nitrocellulose membranes. Blots were incubated with blocking buffer for $1 \mathrm{~h}$ at room temperature and then incubated for $16 \mathrm{~h}$ at $4^{\circ} \mathrm{C}$ with primary antibodies raised to caspase-3 $(1: 1000$, cell signaling technology), PKC $\alpha$ (1:200, Santa Cruz), phospho-ERK1/2 (1:1000, Millipore) and $\beta$-tubulin (internal standard, 1:10000). After incubation with primary antibody, blots were thoroughly washed and then incubated with alkaline phosphatase-conjugated secondary antibody (1:1000, Beyotime) for $2 \mathrm{~h}$ at room temperature. The immunoreactive bands were visualized with a NBT/BCIP color developing reagent.

\section{Statistical analysis}

Numerical data are presented as mean \pm SD. Statistical analysis were conducted with the aid of SPSS 13.0. Differences were evaluated by one-way ANOVA followed by Dunnett's multiple comparison test. $\mathrm{P}<0.05$ was considered statistically significant.

\section{Results}

The effects of ketamine on NSCs proliferation by BrdU incorporation assay

It was found that the percentage of $\mathrm{Nestin}^{+} / \mathrm{BrdU}^{+}$cells in cultured NSCs was not markedly changed by exposure to 10,20 and $50 \mu \mathrm{M}$ ketamine compared to control group ( $p>0.05$, Fig. 1A). However, the percentage of nestin and BrdU double-positive cells was markedly decreased when cultures were exposed to 200, 500, 800 and $1000 \mu \mathrm{M}$ ketamine (Fig. 1B and C).

The effect of ketamine on caspase-3 expression by western blot analysis

We detected the caspase- 3 expression in NSCs exposed to different concentrations of ketamine $(100,200,500,800$ and $1000 \mu \mathrm{M})$ for $24 \mathrm{~h}$. The result showed that ketamine did not significantly affect the expression of caspase-3 (Fig. 2A and B).

\section{Effect of ketamine on [Ca $\left.{ }^{2+}\right]$ i of NSCS}

As shown in Fig. $3 \mathrm{~A}$ and $\mathrm{B}$, the $\left[\mathrm{Ca}^{2+}\right] \mathrm{i}$ of NSCs was markedly decreased after the cells were exposed to $100,200,500,800$ and $1000 \mu \mathrm{M}$ ketamine for $24 \mathrm{~h}$ in DMEM/F12 medium containing calcium ions.

\section{Effects of ketamine on PKC $\alpha$ activation and ERK1/2 phosphorylation}

Western blot analysis of the protein lysates from NSCs exposed to ketamine at different concentrations for $24 \mathrm{~h}$ revealed that the activity of PKC $\alpha$ was markedly inhibited by 200, 500, 800 and $1000 \mu \mathrm{M}$ ketamine. Meanwhile, the phosphorylation level of ERK1/2 was also significantly decreased by 200, 500, 800 and $1000 \mu$ M ketamine (Fig. 4 and Fig. 5). 


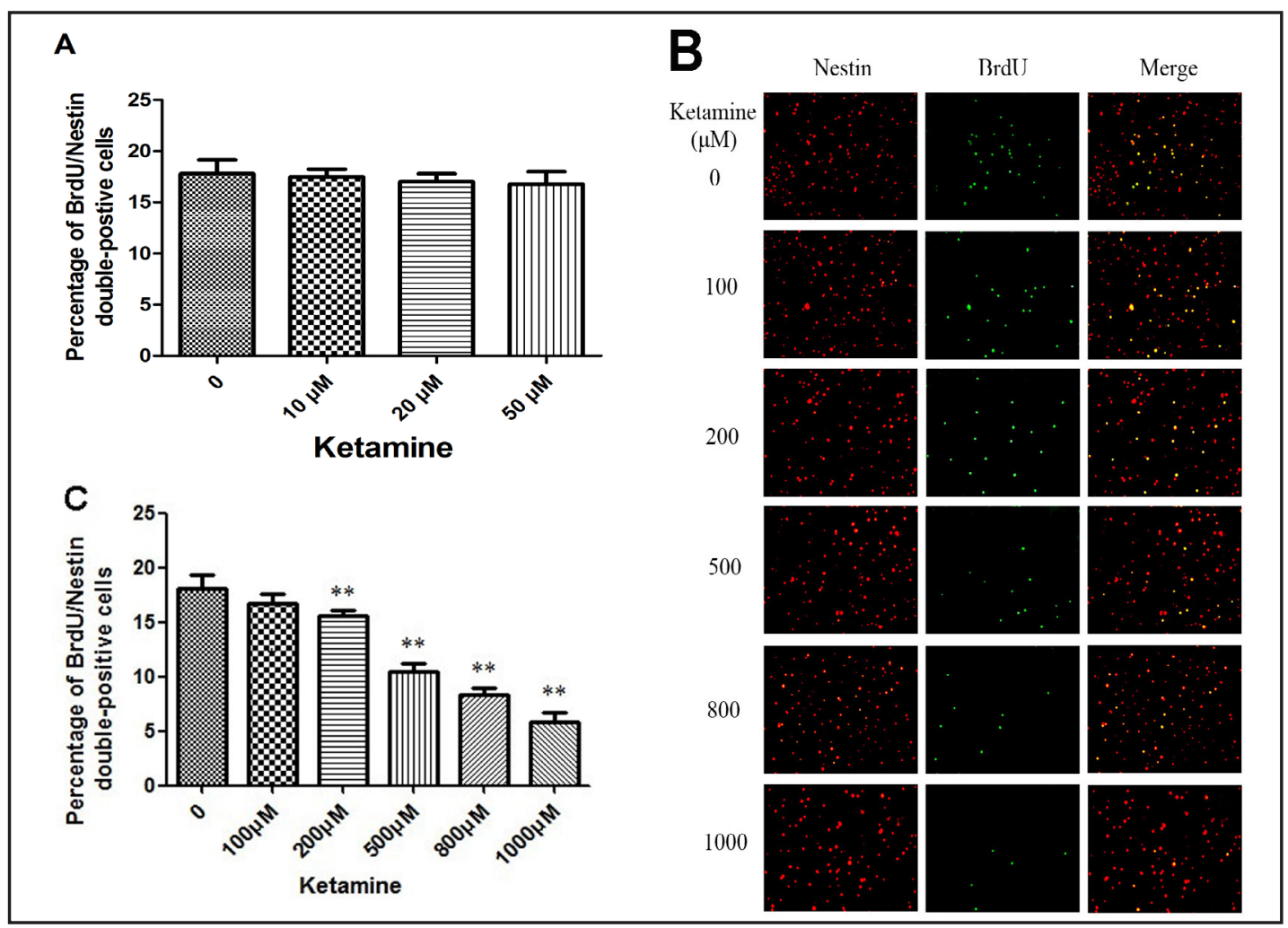

Fig. 1. Effect of ketamine on proliferative activity of NSCs by BrdU incorporation assay. NSCs were cultured and treated with various concentrations of ketamine. The DNA synthesis of NSCs were measured after ketamine treatment for 24 hours. The NSCs were labeled by primary antibodies against NSCs marker nestin and proliferation marker BrdU. Immunoreactive cells were visualized by fluorescence microscopy. The percentage of nestin/BrdU double positive cells was calculated. Data are presented as mean $\pm \mathrm{SD}$. ${ }^{* *} \mathrm{P}<0.01$, vs control $(0 \mu \mathrm{M}$ ketamine $)$ group.

Fig. 2. Effect of ketamine on the expression of caspase-3 in NSCs. NSCs were cultured and treated with various concentrations of ketamine for 24 hours. The caspase- 3 expression was detected by western blot analysis. Data are presented as mean \pm SD.

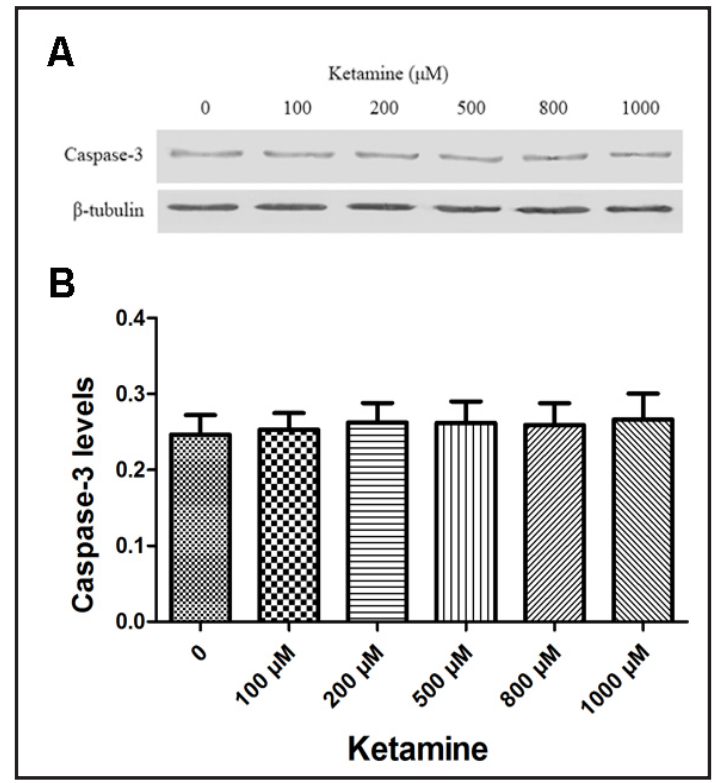

$\mathrm{Ca}^{2+}$ is involved in the inhibition of PKC $\alpha$ activation by ketamine

To determine whether $\mathrm{Ca}^{2+}$ plays a role in the PKC $\alpha$ activation inhibited by ketamine, we used a $\mathrm{Ca}^{2+}$ blocker verapamil to treat NSCs. As shown in Fig. 6A and B, either ketamine (100 

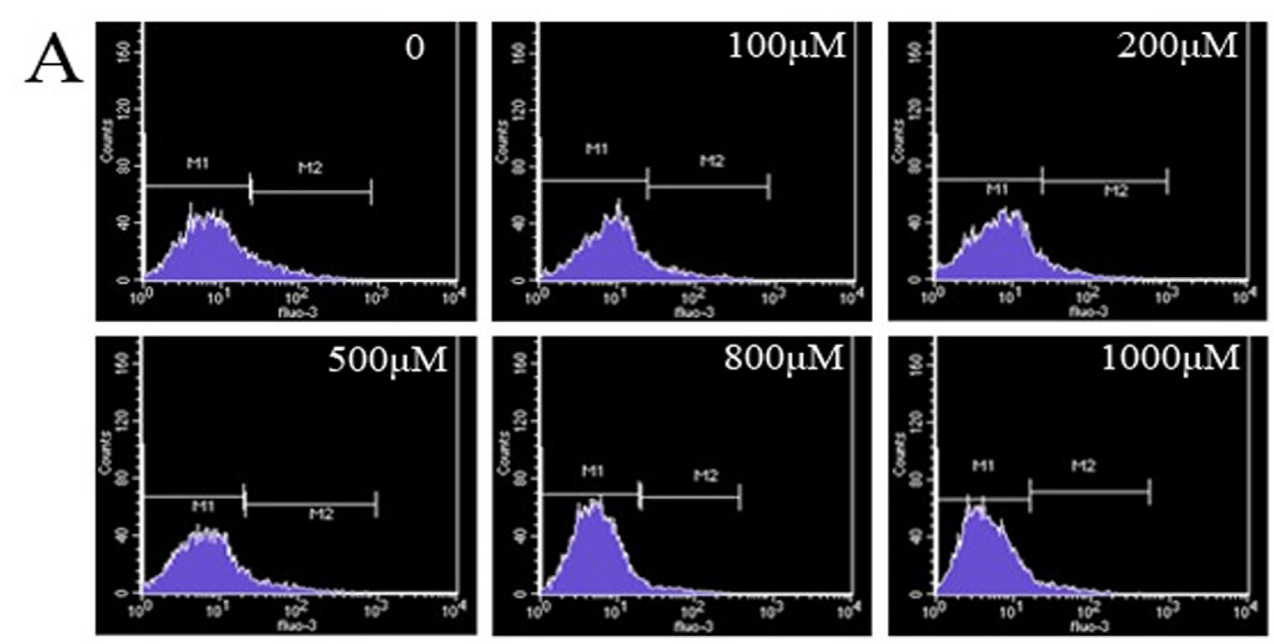

Fig. 3. Intracellular $\mathrm{Ca}^{2+}$ concentration of NSCs after ketamine treatment for $24 \mathrm{~h}$. [ $\left.\mathrm{Ca}^{2+}\right] \mathrm{i}$ was determined with the $\mathrm{Ca}^{2+}$-sensititive Fluo-3/AM by flow cytometer. The intracellular $\mathrm{Ca}^{2+}$ concentrations were significantly decreased after treatment with ketamine. Data are presented as mean \pm SD. ** $\mathrm{p}<0.01$, vs control ( $0 \mu \mathrm{M}$ ketamine) group.
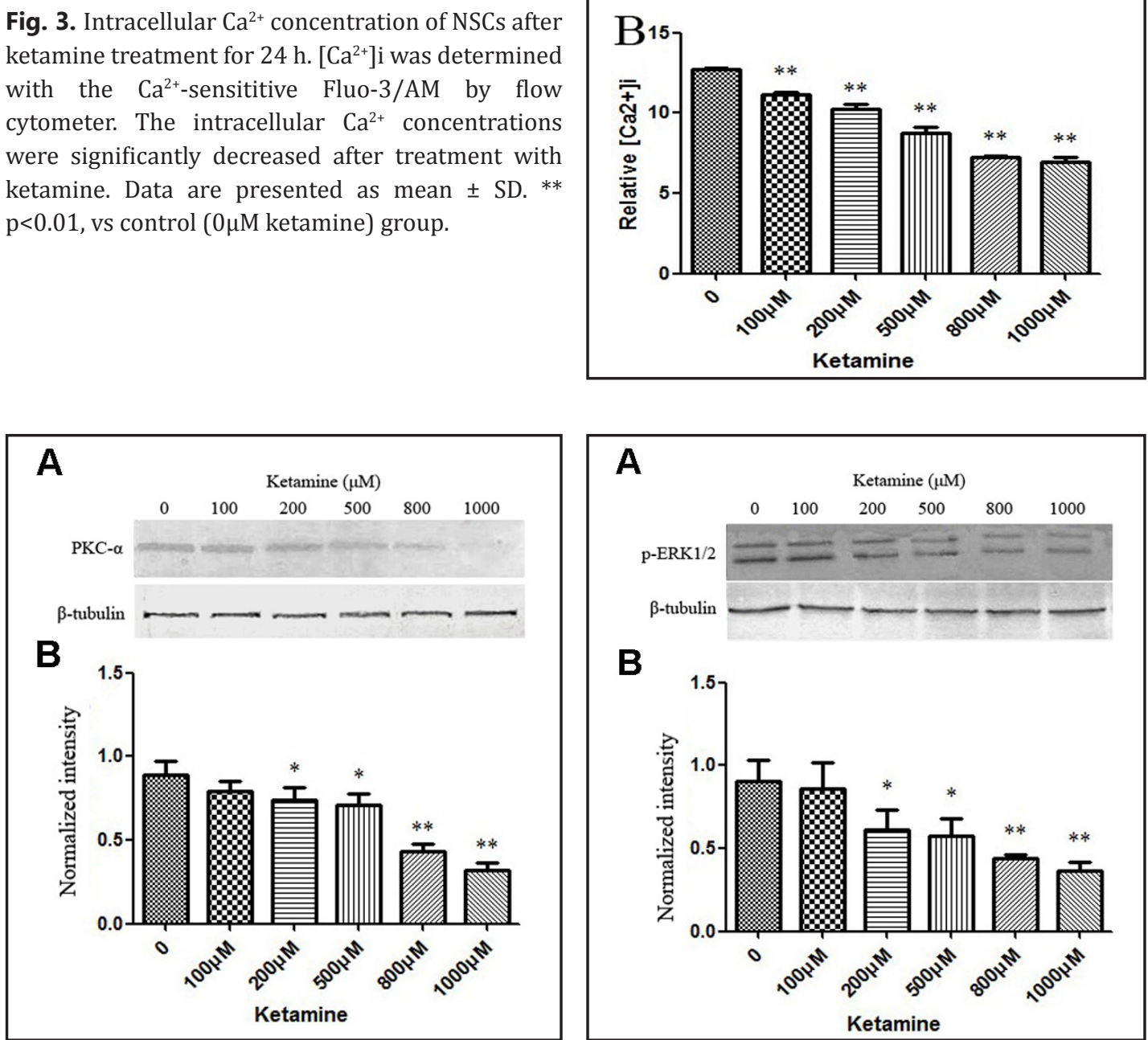

Fig. 4. PKC $\alpha$ activity in NSCs after ketamine treatment for $24 \mathrm{~h}$. The membrane protein was detected by western blot. Ketamine at concentrations of 200, 500, 800 and $1000 \mu \mathrm{M}$ significantly suppressed $\mathrm{PKC} \alpha$ activation. Data are presented as mean \pm SD. * $\mathrm{p}<0.05,{ }^{* *} P<0.01$, vs control $(0 \mu \mathrm{M}$ ketamine $)$ group.

A

A

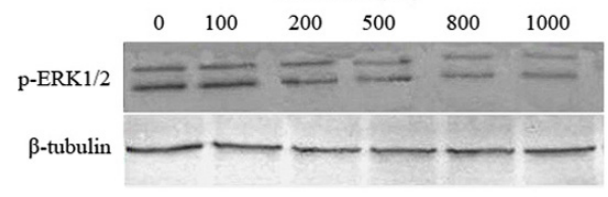

B

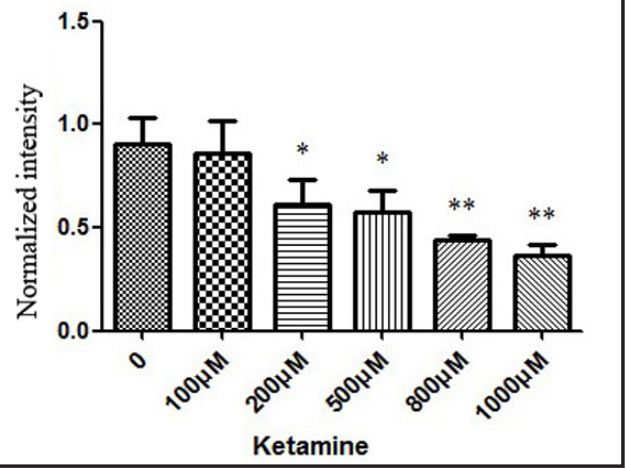

Fig. 5. Phosphorylation of ERK1/2 in NSCs after ketamine treatment for $24 \mathrm{~h}$ by western blot. Ketamine at concentrations of 200,500, 800 and 1000 $\mu \mathrm{M}$ significantly suppressed the phosphorylation of ERK1/2. Data are presented as mean \pm SD. ${ }^{*} \mathrm{p}<0.05$, ${ }^{* *} P<0.01$, vs control $(0 \mu \mathrm{M}$ ketamine $)$ group. 


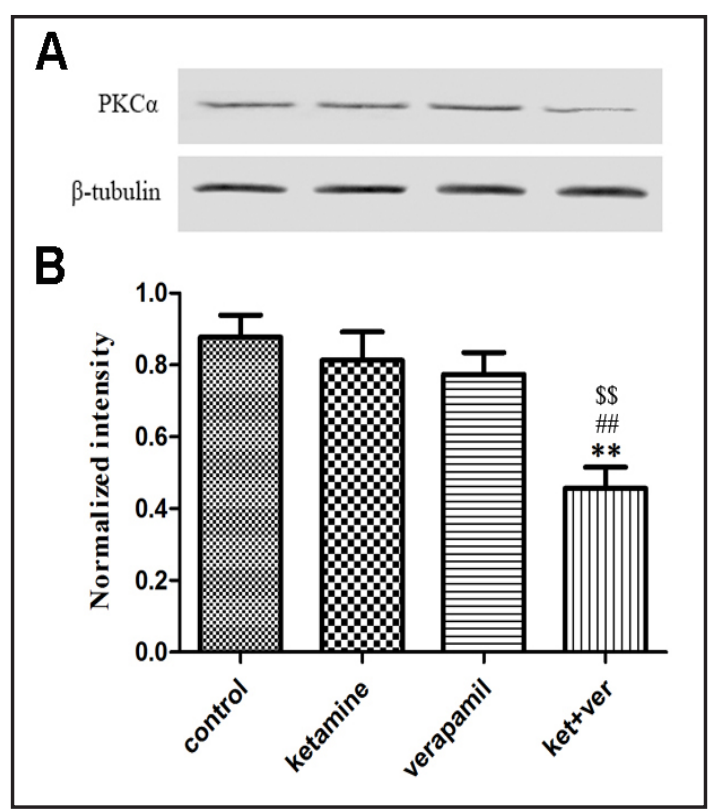

Fig. 6. The effect of ketamine and verapamil on PKC- $\alpha$ activation in NSCs. The expression of cell membrane PKC- $\alpha$ was measured by western blot analysis. Subthreshold concentrations of either ketamine $(100 \mu \mathrm{M})$ or verapamil $(2.5 \mu \mathrm{M})$ did not significantly inhibit PKC $\alpha$ activation. However, suprathreshold effect was produced by the combined administration of $100 \mu \mathrm{M}$ ketamine and $2.5 \mu \mathrm{M}$ verapamil. The data are presented as mean \pm SD. ${ }^{* *} \mathrm{P}<0.01$,

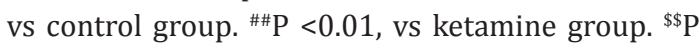
$<0.01$, vs verapamil group.

Fig. 8. The effect of ketamine and PD98059 on NSC proliferation by BrdU incorporation assay. Subthreshold concentrations of either ketamine $(100 \mu \mathrm{M})$ or PD98059 $(5 \mu \mathrm{M})$ did not significantly inhibit NSC proliferation. However, the suprathreshold effect was produced by the combined administration of $100 \mu \mathrm{M}$ ketamine and $5 \mu \mathrm{M}$ PD98059. The data are presented as mean $\pm \mathrm{SD}$. ${ }^{* *} \mathrm{P}<0.01$, vs control group.

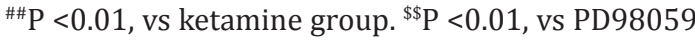
group.

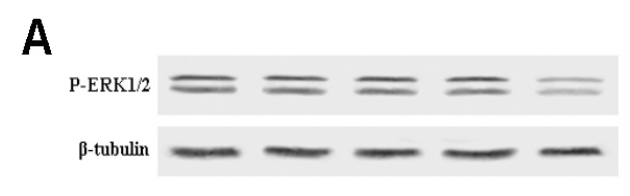

B

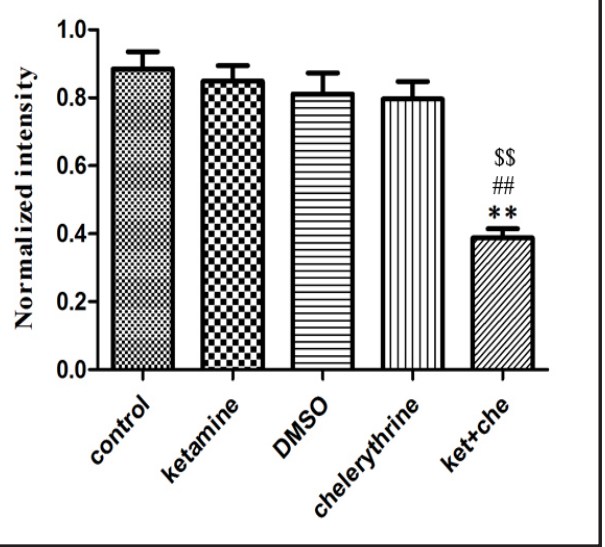

Fig. 7. The effect of ketamine and chelerythrine on ERK1/2 phosphorylation in NSCs. The expression of phosphorylated ERK1/2 was measured by western blot analysis. Subthreshold concentrations of either ketamine $(100 \mu \mathrm{M})$ or chelerythrine $(2.5 \mu \mathrm{M})$ did not significantly inhibit ERK1/2 phosphorylation. However, suprathreshold effect were produced by the combined administration of $100 \mu \mathrm{M}$ ketamine and $2.5 \mu \mathrm{M}$ chelerythrine. The data are presented as mean $\pm \mathrm{SD} .{ }^{* *} \mathrm{P}<0.01$, vs control group. ${ }^{\# \# P}<0.01$, vs ketamine group. ${ }^{\$} \mathrm{P}<0.01$, vs chelerythrine group.

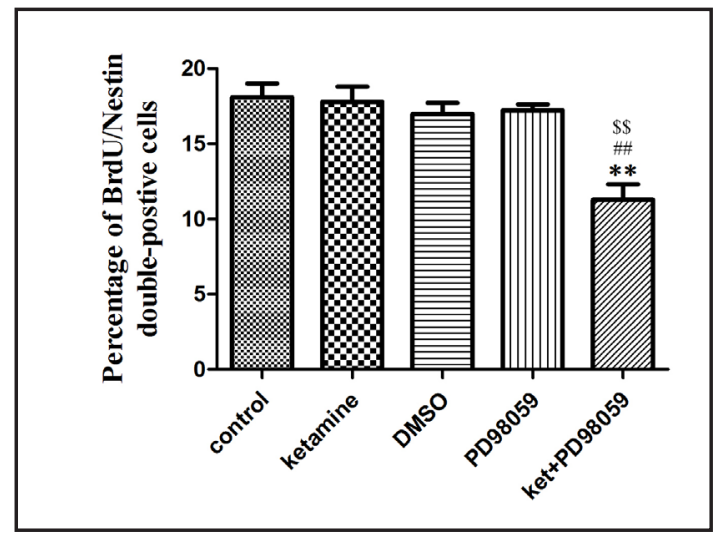

$\mu \mathrm{M})$ or verapamil $(2.5 \mu \mathrm{M})$ did not significantly inhibit PKC $\alpha$ activation. However, when the cells were treated with $100 \mu \mathrm{M}$ ketamine combined with $2.5 \mu \mathrm{M}$ verapamil, the effect was markedly suppressed.

PKC $\alpha$ is involved in the inhibition of ERK1/2 phosphorylation by ketamine

It was found that either ketamine $(100 \mu \mathrm{M})$ or chelerythrine $(2.5 \mu \mathrm{M})$ did not significantly inhibit ERK1/2 phosphorylation. However, when the cells were treated with 
$100 \mu \mathrm{M}$ ketamine combined with $2.5 \mu \mathrm{M}$ chelerythrine, the phosphorylation of ERK1/2 was markedly decreased (Fig. 7A and B).

\section{ERK1/2 is involved in the inhibition of NSC proliferation by ketamine}

Ketamine $(100 \mu \mathrm{M})$ and PD98059 $(5 \mu \mathrm{M})$ could not significantly inhibit NSC proliferation respectively. However, when the cells were treated with $100 \mu \mathrm{M}$ ketamine combined with 5 $\mu$ M PD98059, NSC proliferation was markedly inhibited (Fig. 8).

\section{Discussion}

Ketamine, a noncompetitive NMDA receptor antagonist, has been reported to induce apoptotic neurodegeneration in the developing brain [16-19]. However, the effect of ketamine on neurogenesis during a critical stage of brain development has not been clarified. Given the importance of neural stem cells (NSCs) proliferation in neurogenesis, we firstly investigated the effect of ketamine on proliferation of hippocampal NSCs from neonatal rats in vitro and relevant mechanisms.

NSCs are self-renewal and multipotential cells that can generate differentiated progeny such as neurons and glia. NSCs play an important role in neurogenesis and gliogenesis in the development of the central nervous system. In humans, the brain growth spurt (BGS) proceeds from the third trimester until approximately 2 years after birth. In rats, this period corresponds to the first 21 postnatal days (PNDs) [20]. In this study, to observe NSC proliferation during the period equivalent to human BGS, we investigated the effects of ketamine on hippocampal NSC proliferation in vitro using PND3 rats. The process of hippocampal neurogenesis involves proliferation of NSCs, differentiation into neurons and glia, migration and functional integration into the hippocampal circuitry [11, 12]. In this complicated neurogenesis process, the proliferation of hippocampal NSCs was not only initial but also very crucial. In the present study, NSCs formed enough neurospheres. Then immunofluorescence for nestin (a specific protein in NSCs) was performed to identify that neurospheres were constitutive of NSCs. In addition, we detected differentiated neurons and astrocytes from cultured NSCs by immunofluorescence technology using specific antibodies. All the results demonstrated that the cells obtained for experiments were NSCs.

Our findings documented that ketamine $(10,20,50$ and $100 \mu \mathrm{M})$ could not significantly affect the proliferation of NSCs. Our results were different from previous finding by Bai et al which reported that exposure to $100 \mu \mathrm{M}$ ketamine for 6 hours could promote the proliferation of NSCs from human embryonic stem cells (hESCs) in vitro [21]. This discrepancy may be attributed to the different NSCs source and ketamine exposure duration. Another study by Dong et al reported that ketamine $(20,50$ and $100 \mu \mathrm{M})$ could inhibit the proliferation of NSCs derived from the cortex of Sprague-Dawley rat on embryonic day 17 in vitro [22]. We consider that the NSCs derived from the cortex of embryonic day 17 rat may have different biological characteristics compared to NSCs isolated from the hippocampus of postnatal day 3 rat, which lead to different reaction to anesthetics. In addition, our results showed the higher concentrations of ketamine $(200,500,800$ and $1000 \mu \mathrm{M})$ could significantly inhibit proliferation of hippocampal NSCs from neonatal rats by BrdU incorporation assay. Meanwhile, these higher concentrations of ketamine did not markedly promote NSCs apoptosis (Fig. 2). It suggested that the decreased percentage of Nestin/BrdU double-postive cells was mainly caused by inhibiting the proliferation of NSCs by ketamine.

The NMDA-R is a tetramer or pentamer consisted of NMDAR-1 subunit (NR1) and several NMDAR-2 subunit (NR2). Previous research had reported that NR1, NR2A and NR2B were expressed in the NSCs [22]. However, the role of NMDA-R in the proliferation of hippocampal NSCs remains controversial [23, 24]. NMDAR is a specific type of ionotropic glutamate receptor, which can allow the passage of $\mathrm{Ca}^{2+}$ and $\mathrm{Na}^{+}$into the cell and $\mathrm{K}^{+}$out of the cell, mainly the flux of $\mathrm{Ca}^{2+}[25]$. The $\mathrm{Ca}^{2+}$ can in turn function as a second messenger in various signaling pathways. Intracellular calcium signal plays an important role in the 
control of cellular proliferation $[26,27]$. To clarify the mechanism by which ketamine exerts its inhibitory effect on NSCs proliferation, we observed the effect of ketamine on intracellular $\mathrm{Ca}^{2+}$ concentration in the presence of B27 without vitamin A, epidermal growth factor (EGF) and basic fibroblast growth factor (bFGF). The results showed that ketamine markedly decreased intracellular $\mathrm{Ca}^{2+}$ concentration of NSCs from neonatal rat hippocampus (Fig. 3). It indicated that ketamine may exert its suppressive effect on NSCs proliferation through inhibiting intracellular calcium signal.

As a second messenger, $\mathrm{Ca}^{2+}$ can activate a series of $\mathrm{Ca}^{2+}$-dependent protein kinase $\mathrm{C}$ (PKC). PKC is a family of serine/threonine kinases that plays an important role in modulating a variety of biological responses including the regulation of cell growth. There are three well-characterized MAPK subfamilies in mammalian cell: extracellular signal-regulated kinases 1/2 (ERK1/2), c-Jun N-terminal kinases (JNKs)/stress-activated protein kinases (SAPKs) and p38 MAPK. The activation of ERK1/2 has been shown to lead to cellular proliferation, whereas JNK and p38 MAPK activation is associated with inflammatory cytokine action, cellular stress and apoptosis $[28,29]$. MAPK/ERK1/2 can be activated through PKC-dependent mechanism [30]. To clarify the mechanism by which ketamine exerts its inhibitory effect on NSC proliferation, we observed the effect of ketamine on PKC $\alpha$ and ERK1/2 activation. The results showed that ketamine $(200,500,800$ and $1000 \mu \mathrm{M})$ markedly suppressed PKC $\alpha$ activation (Fig. 4) and ERK1/2 phosphorylation (Fig. 5) in NSCs from neonatal rat hippocampus.

To determine whether the inhibitory effect on PKC $\alpha$ activation by ketamine was mediated through interfering $\mathrm{Ca}^{2+}$ signaling, the effects of subthreshold concentrations of ketamine $(100 \mu \mathrm{M})$ and verapamil $(2.5 \mu \mathrm{M})$ on PKC $\alpha$ activation were studied. The result showed neither $100 \mu \mathrm{M}$ ketamine nor $2.5 \mu \mathrm{M}$ verapamil significantly inhibited PKC $\alpha$ activation in NSCs. However, the PKC $\alpha$ activation was markedly suppressed by combined treatment with $100 \mu \mathrm{M}$ ketamine and $2.5 \mu \mathrm{M}$ verapamil (Fig. 6), suggesting that ketamine and verapamil should mutually enhance the effect of the other side by the same mechanism and then reach to a suprathreshold effect. Based on the results above, we considered that ketamine may suppress PKC $\alpha$ activation by inhibiting calcium signaling in NSCs.

To determine whether PKC $\alpha$ is involved in the inhibitory effect of ketamine on ERK1/2 phosphorylation, the effects of subthreshold concentrations of ketamine $(100 \mu \mathrm{M})$ and PKC $\alpha$ inhibitor chelerythrine $(2.5 \mu \mathrm{M})$ on ERK1/2 phosphorylation were explored. The result showed neither $100 \mu \mathrm{M}$ ketamine nor $2.5 \mu \mathrm{M}$ chelerythrine significantly inhibited ERK1/2 phosphorylation in NSCs. However, combined treatment with $100 \mu \mathrm{M}$ ketamine and $2.5 \mu \mathrm{M}$ chelerythrine markedly suppressed ERK1/2 phosphorylation (Fig. 7). It suggested that ketamine and chelerythrine may mutually enhance the effect of the other side by the same mechanism and then reach to a suprathreshold effect. Based on the results above, we considered that ketamine may suppress ERK1/2 phosphorylation by inhibiting PKC $\alpha$ activation in NSCs.

It was also showed that neither $100 \mu \mathrm{M}$ ketamine nor $5 \mu \mathrm{M}$ PD98059 markedly inhibited NSC proliferation. However, the combined treatment with $100 \mu \mathrm{M}$ ketamine and $5 \mu$ M PD98059 significantly inhibited NSC proliferation (Fig. 8). This result indicated that ketamine and PD98059 at their respective subthreshold concentrations may mutually enhance each other's effects by the same mechanism, resulting in a suprathreshold effect. Based on these results, we considered the possibility that ketamine can suppress NSC proliferation by inhibiting ERK1/2 phosphorylation.

A previous study demonstrated that plasma levels of ketamine varied from 37.8-108.4 $\mu \mathrm{M}$ in patients 1 minute after intravenous ketamine injection at a dose of $2.0-2.2 \mathrm{mg} / \mathrm{kg}$ [31]. Thus, a ketamine concentration of within $100 \mu \mathrm{M}$ is observed in vivo. The present study indicated that ketamine $(10,20,50$ and $100 \mu \mathrm{M})$ failed to alter the proliferation of NSCs from neonatal rat hippocampus in vitro. While ketamine at the concentrations of 200, 500, 800 and $1000 \mu \mathrm{M}$ significantly inhibited the proliferation of NSCs through attenuating $\mathrm{Ca}^{2+}-\mathrm{PKC} \alpha-$ ERK1/2 signal in vitro. Our results suggested that the direct inhibitory effect of ketamine on NSCs proliferation in vitro was evident only at the higher concentrations. While clinical 
relevant concentrations of ketamine were not enough to directly alter the proliferation of NSCs in vitro. However, the circumstances for NSCs development in vivo were very different from those in vitro and it is possible that ketamine interferes the proliferation of NSCs by both direct and indirect pathways in vivo. Therefore, it is necessary to further investigate the effects of clinical relevant doses of anesthetics on NSC function in vivo.

\section{Acknowledgments}

This work was supported by Key Subject of Natural Science Foundation of Jiangsu Higher Education Institutions (10KJA320052), National Natural Science Foundation of China $(81171013,81070889)$ and A Project Funded by the Priority Academic Program Development of Jiangsu Higher Education Institutions. We declare that there is no conflict of interest that would prejudice its impartiality.

\section{References}

1 Mellon RD, Simone AF, Rappaport BA: Use of anesthetic agents in neonates and young children. Anesth Analg 2007;104:509-520.

- Ikonomidou C, Bosch F, Miksa M, Bittigau P, Vockler J, Dikranian K, Tenkova TI, Stefovska V, Turski L, Olney JW: Blockade of NMDA receptors and apoptotic neurodegeneration in the developing brain. Science 1999;283:70-74.

- Z Zou X, Patterson TA, Sadovova N, Twaddle NC, Doerge DR, Zhang X, Fu X, Hanig JP, Paule MG, Slikker W, Wang C: Potential Neurotoxicity of Ketamine in the Developing Rat Brain. Toxicol Sci 2009;108:149-158.

-4 Slikker W Jr, Zou X, Hotchkiss CE, Divine RL, Sadovova N, Twaddle NC, Doerge DR, Scallet AC, Patterson TA, Hanig JP, Paule MG, Wang C: Ketamine-induced neuronal cell death in the perinatal rhesus monkey. Toxicol Sci 2007;98:145-158.

-5 Zou X, Patterson TA, Divine RL, Sadovova N, Zhang X, Hanig JP, Paule MG, Slikker W Jr, Wang C: Prolonged exposure to ketamine increases neurodegeneration in the developing monkey brain. Int J Dev Neurosci 2009;27:727-731.

-6 Fredriksson A, Pontén E, Gordh T, Eriksson P: Neonatal exposure to a combination of N-methyl-D-aspartate and gamma-aminobutyric acid type A receptor anesthetic agents potentiates apoptotic neurodegeneration and persistent behavioral deficits. Anesthesiology 2007;107:427-436.

7 Paule MG, Li M, Allen RR, Liu F, Zou X, Hotchkiss C, Hanig JP, Patterson TA, Slikker W Jr, Wang C: Ketamine anesthesia during the first week of life can cause long-lasting cognitive deficits in rhesus monkeys. Neurotoxicol Teratol 2011;33:220-230.

-8 Wilder RT, Flick RP, Sprung J, Katusic SK, Barbaresi WJ, Mickelson C, Gleich SJ, Schroeder DR, Weaver AL, Warner DO: Early exposure to anesthesia and learning disabilities in a population-based birth cohort. Anesthesiology 2009;110:796-804.

-9 Kalkman CJ, Peelen L, Moons KG, Veenhuizen M, Bruens M, Sinnema G, de Jong TP: Behavior and development in children and age at the time of first anesthetic exposure. Anesthesiology 2009;110:805-812.

10 Dupret D, Revest JM, Koehl M, Ichas F, De Giorgi F, Costet P, Abrous DN, Piazza PV: Spatial relational memory requires hippocampal adult neurogenesis. PLoS ONE 2008;3:e1959.

11 Zhao C, Deng W, Gage FH: Mechanisms and functional implications of adult neurogenesis. Cell 2008;132:645-660.

12 Piatti VC, Esposito MS, Schinder AF: The timing of neuronal development in adult hippocampal neurogenesis. Neuroscientist 2006;12:463-468.

13 Reynolds BA, Weiss S: Generation of neurons and astrocytes from isolated cells of the adult mammalian central nervous system. Science 1992;255:1707-1710.

14 Kanemura Y, Mori H, Kobayashi S, Islam O, Kodama E, Yamamoto A, Nakanishi Y, Arita N, Yamasaki M, Okano H, Hara M, Miyake J: Evaluation of in vitro proliferative activity of human fetal neural stem/ progenitor cells using indirect measurements of viable cells based on cellular metabolic activity. J Neurosci Res 2002;69:869-879. 
15 Burchiel SW, Edwards BS, Kuckuck FW, Lauer FT, Prossnitz ER, Ransom JT, Sklar LA: Analysis of free intracellular calcium by flow cytometry: multiparameter and pharmacologic applications. Methods 2000;21:221-230.

16 Wang C, Sadovova N, Fu X, Schmued L, Scallet A, Hanig J, Slikker W: The role of the N-methyl-D-aspartate receptor in ketamine-induced apoptosis in rat forebrain culture. Neuroscience 2005;132:967-977.

-17 Wang C, Sadovova N, Hotchkiss C, Fu X, Scallet AC, Patterson TA, Hanig J, Paule MG, Slikker W Jr: Blockade of N-Methyl- D-aspartate receptors by ketamine produces loss of postnatal day 3 monkey frontal cortical neurons in culture. Toxicol Sci 2006;91:192-201.

- 18 Ikonomidou C, Bosch C, Miksa M, Bittigau P, Vockler J, Dikranian K, Tenkova TI, Stefovska V, Turski L, Olney JW: Blockade of NMDA receptors and apoptotic neurodegeneration in the developing brain. Science 1999;283:70-74.

19 Liu F, Paule MG, Ali S, Wang C: Ketamine-induced neurotoxicity and changes in gene expression in the developing rat brain. Curr Neuropharmacol 2011;9:256-261.

20 Bayer SA, Altman J, Russo RJ, Zhang X: Timetables of neurogenesis in the human brain based on experimentally determined patterns in the rat. Neurotoxicology 1993;14:83-144.

-21 Bai X, Yan Y, Canfield S, Muravyeva MY, Kikuchi C, Zaja, I, Corbett J A, Bosnjak, ZJ: Ketamine enhances human neural stem cell proliferation and induces neuronal apoptosis via reactive oxygen species-mediated mitochondrial pathway. Anesth Analg 2013;116:869-880.

22 Dong C, Rovnaghi CR, Anand KJ: Ketamine alters the neurogenesis of rat cortical neural stem progenitor cells. Crit Care Med 2012;40:2407-2416.

23 Kitayama T, Yoneyama M, Tamaki K, Yoneda Y: Regulation of neuronal differentiation by N-methyl-Daspartate receptors expressed in neural progenitor cells isolated from adult mouse hippocampus. J Neurosci Res 2004;76:599-612.

-24 Tamaki K, Yamada K, Nakamichi N, Taniura H, Yoneda Y: Transient suppression of progenitor cell proliferation through NMDA receptors in hippocampal dentate gyrus of mice with traumatic stress experience. J Neurochem 2008;105:1642-1655.

25 Paoletti P, Neyton J: NMDA receptor subunits: function and pharmacology. Curr Opin Pharmacol 2007;1:3947.

26 Xu Z, Yan L, Ge Y, Zhang Q, Yang N, Zhang M, Zhao Y, Sun P, Gao J, Tao Z, Yang Z: Effect of the calcium sensing receptor on rat bone marrow-derived mesenchymal stem cell proliferation through the ERK1/2 pathway. Mol Biol Rep 2012;39:7271-7279.

27 Fiorio Pla A, Maric D, Brazer SC, Giacobini P, Liu X, Chang YH, Ambudkar IS, Barker JL: Canonical transient receptor potential 1 plays a role in basic fibroblast growth factor (bFGF)/FGF receptor-1-induced Ca2+ entry and embryonic rat neural stem cell proliferation. J Neurosci 2005;25:2687-2701.

28 Hommes DW, Peppelenbosch MP, van Deventer SJ: Mitogen activated protein (MAP) kinase signal transduction pathways and novel anti-inflammatory targets. Gut 2003;52:144-151.

29 Robinson MJ, Cobb MH: Mitogen-activated protein kinase pathways. Curr Opin Cell Biol 1997;9:180-186.

-30 Resende RR, Adhikari A: Cholinergic receptor pathways involved in apoptosis, cell proliferation and neuronal differentiation. Cell Commun Signal 2009;7:20.

- 31 Domino EF, Zsigmond EK, Domino LE, Domino KE, Kothary SP, Domino SE: Plasma levels of ketamine and two of its metabolites in surgical patients using a gas chromatographic mass fragmentographic assay. Anesth Analg 1982;61:87-92. 